\title{
Extraordinary Meetings of the Medico-Psychological Society of Paris.
}

The Medico-Psychological Society of Paris has organised extraordinary meetings for the week preceding the time fixed for the General and Universal Medical Congress of Paris of this year, viz. on August 10th, 11th, and 14th. The meetings will take place at the Faculty of Medicine, at four in the afternoon. Full liberty is left as to the choice of the subjects for papers; but the Society would direct attention to the following topics :-

1. Appropriate legislation and mode of relief for the insane in different countries.

2. Relations of insanity to private and public educntion.

3. Basis of a general system of asylum statistics.

4. On the pathological changes of the nervous centres in the various forms of insanily, and especially on the progress effected in this respect by the use of the microscope.

The members of the Medico-Psychological Association are invited to attend. We are requested to add to this statement the earnest wish of the Societe Médico-Psychologique that the English Association may be farly represented at this congress.

\section{Notice to Correspondents.}

English books for review, pamphlets, exchange journals, \&c., to be sent either by book-post to Dr. Robertson, Hayward's Heath, Sussex; or to the care of the publishers of the Journal, Messrs. Churchill and Sons, New Burlington Street. French, German, and American publications may be forwarded to Dr. Robertson, by foreign book-post, or to Messrs. Williams and Norgate, Henrietta Street, Covent Garden, to the care of their German, French, and American agents, Mr. Hartmann, Leipzig; M. Borrari, 9, Rue de St. Pères, Paris ; Messrs. Westermann and Co., Broadway, New York.

Authors of Original Papers wishing Reprints for private circulation can have them on application to the Printer of the Journal, Mr. Adlard, Bartholomew Close, E.C., at a fixed charge of 30 s. per sheet per 100 copies, including a coloured wrapper and title-page.

The copies of The Journal of Mental Science are regularly sent by Book-post (prepaid) to the ordinary Members of the Association, and to our Home and Foreign Correspondents ; and Dr. Robertson will be glad to be informed of any irregularity in their receipt or overcharge in the Postage.

The following EXCHANGE JOURNALS have been regularly receired since our last publication:

The Annales Médico-Psychologiques; the Zeitschrift fïr Psychiatrie; the Correspondenz Blatt der deutschen Gesellschaft für Psychiatrie; Archiv für Psy. chiatrie; the Irren Freund; Journal de Médecine Mentale; Archivio Italiuno per le Mabattie Nervose e per le Alienazioni Mentali; Medizinische Jahrbücher

voL. XIII. 
(Zeitschrift der K. K. Gesellschaft der Aerzte in Wien); the Edinburgh Medical Journal; the American Journal of Insanity; the British and Foreign MedicoChirurgical Review; the Dublin Quarterly Journal; the Medical Mirror; the British Medical Journal; the Medical Circular; the Journal of the Society of Arts; and New York Medical Journal. Also the Morningside Mirror; the York Star; Excelsior, or the Murray Royal Institution Literary Gazette.

\section{ERRATA.}

In an article eutitled "Contributions to the Pathology of Nervous Diseases," in the April number of the Journal, the following errors make nonsense of an im. portant passage. We quote the passage, marking the errors by italics. "It is clear that the left hemisphere was cut off both from knowledge of, and power of acting upon the limbs of the opposite (should be same) side; for, although it was in full function, the patient was unaware of her hemiplegia-the left (should be right) being so disintegrated as to be unconscious of it. And the example would seem to show that one hemisphere can only act volitionally on the limbs of the same (should be opposite) side ...... And of course if the hemiplegia was not real, there was no reason why the right (should be left) hemisphere should not have been able to act upon the limbs, except that it was cut off from communi-
cation." 